\title{
Determination of Natural Radioactivity in the North East Beach Sands of Madagascar
}

\author{
Randriamora Tiana Harimalala ${ }^{1}$, Razafindramiandra Hary Andrianarimanana ${ }^{1}$, \\ Raoelina Andriambololona ${ }^{3}$, Ravelomanantsoa Solofonirina Dieudonné ${ }^{4}$, \\ Ralaivelo Mbolatiana Anjarasoa Luc ${ }^{1}$, Rasolonirina Martin ${ }^{2}$, \\ Zafimanjato Joseph Lucien Radaorolala ${ }^{1}$, Randriantseheno Hery Fanja ${ }^{1}$ \\ ${ }^{1}$ Department of Dosimetry and Radiation Protection, National Institute of Sciences and Nuclear Techniques (INSTN-Madagascar), \\ Antananarivo, Madagascar \\ ${ }^{2}$ Department of Nuclear Techniques and Analysis, National Institute of Sciences and Nuclear Techniques (INSTN-Madagascar), \\ Antananarivo, Madagascar \\ ${ }^{3}$ Department of Theoretical Physics, National Institute of Sciences and Nuclear Techniques (INSTN-Madagascar), Antananarivo, \\ Madagascar \\ ${ }^{4}$ Department of Physics, Faculty of Sciences, University of Antananarivo, Antananarivo, Madagascar
}

Email address:

rlatinah@yahoo.fr (R. T. Harimalala)

To cite this article:

Randriamora Tiana Harimalala, Razafindramiandra Hary Andrianarimanana, Raoelina Andriambololona, Ravelomanantsoa Solofonirina Dieudonné, Ralaivelo Mbolatiana Anjarasoa Luc, Rasolonirina Martin, Zafimanjato Joseph Lucien Radaorolala, Randriantseheno Hery Fanja. Determination of Natural Radioactivity in the North East Beach Sands of Madagascar. American Journal of Physics and Applications. Vol. 5, No. 1, 2017, pp. 6-12. doi: 10.11648/j.ajpa.20170501.12

Received: December 30, 2016; Accepted: January 17, 2017; Published: February 13, 2017

\begin{abstract}
Exploration and exploitation of radioactive ores (ilmenite, zircon and monazite) are considered as the main source of exposure to ionizing radiation of the population living in the coast of Analanjorofo Region (Fénérive-Est Districts, Rural municipality Ampasimbe Manantsatrana). Radioactivity measurements have been performed in this region. The distribution of natural radionuclide gamma-emitters $\left({ }^{238} \mathrm{U},{ }^{232} \mathrm{Th}\right.$ and $\left.{ }^{40} \mathrm{~K}\right)$ and their respective annual effective dose rates have been determined for sand(s), water and air. The samples have been collected along and around the coast of the region. The radiation emitted from the natural radionuclide containing in the environmental samples has been determined by gamma spectrometry system and Radon meter (SARAD). Exposure dose rates at $1 \mathrm{~m}$ above the ground have been measured along the coast and in the villages around the exploitation sites. Dose rate measurements have been performed by Dosimeter Graetz X5 DE, equipped of Geiger Müller Counter. Results have been compared with the reference values provided by IAEA (BSS 115) and UNSCEAR 2000.
\end{abstract}

Keywords: Coastal Sands, ${ }^{238} \mathrm{U},{ }^{232} \mathrm{Th}$ and ${ }^{40} \mathrm{~K}$ Concentrations, Annual Effective Dose Rate, Gamma Spectrometry, Geiger Müller Counter

\section{Introduction}

Natural radioactivity represents the main source of human exposure to ionizing radiation. Public and workers are exposed to natural radionuclides from the environment via external and internal pathways. The terrestrial gamma rays are essentially derived from ${ }^{40} \mathrm{~K}$ and radionuclides belonging to ${ }^{238} \mathrm{U}$ and ${ }^{232} \mathrm{Th}$ series that are present in the earth's crust [6].

The study of the distribution of primordial radionuclides allows the understanding of the radiological contribution of these elements due to the $\gamma$-ray exposure of the body and irradiation of lung tissues from inhalation of radon and its daughters. It represents a significant asset to the assessment of the radiation hazards associated with the exploitation of radioactive ores. Hence, the assessment of gamma radiation dose from radioactive ores presents a particular importance to study the contribution of external and internal doses for public around the sites and workers in the sites. The dose rates vary depending upon the concentration of the natural 
radionuclides such as ${ }^{238} \mathrm{U}$ and ${ }^{232} \mathrm{Th}$ series, and ${ }^{40} \mathrm{~K}$ present in water, sand and air [5].

The objective of this study is to evaluate the natural levels of radioactivity from radioactive ores in the study areas and surrounding villages; to quantify the impact of activities related to the exploitation of radioactive ores; to ensure the radiological protection of workers in the site, handling radioactive substances, and publics living around the sites.

Laboratory measurements are performed by gamma spectrometry system using $\mathrm{NaI}(\mathrm{Tl})$ detector in order to determine the natural radionuclide activities in soil, sand and water samples. The annual effective dose rates and external hazard indexes have been evaluated and compared to the limits proposed by United Nations Scientific Committee on the Effects of Atomic Radiation (UNSCEAR, 2000) and the measurements of dose rate have been carried out using GRAETZ X5 DE Ratemeter equipped with Geiger Muller detector.

\section{Location and Delimitation of Study Site}

The investigated area is located in the north-east of Madagascar, Region of Analanjirofo, District of Fenoarivo Atsinanana, Rural Commune of Ampasimbe (Figure 1).

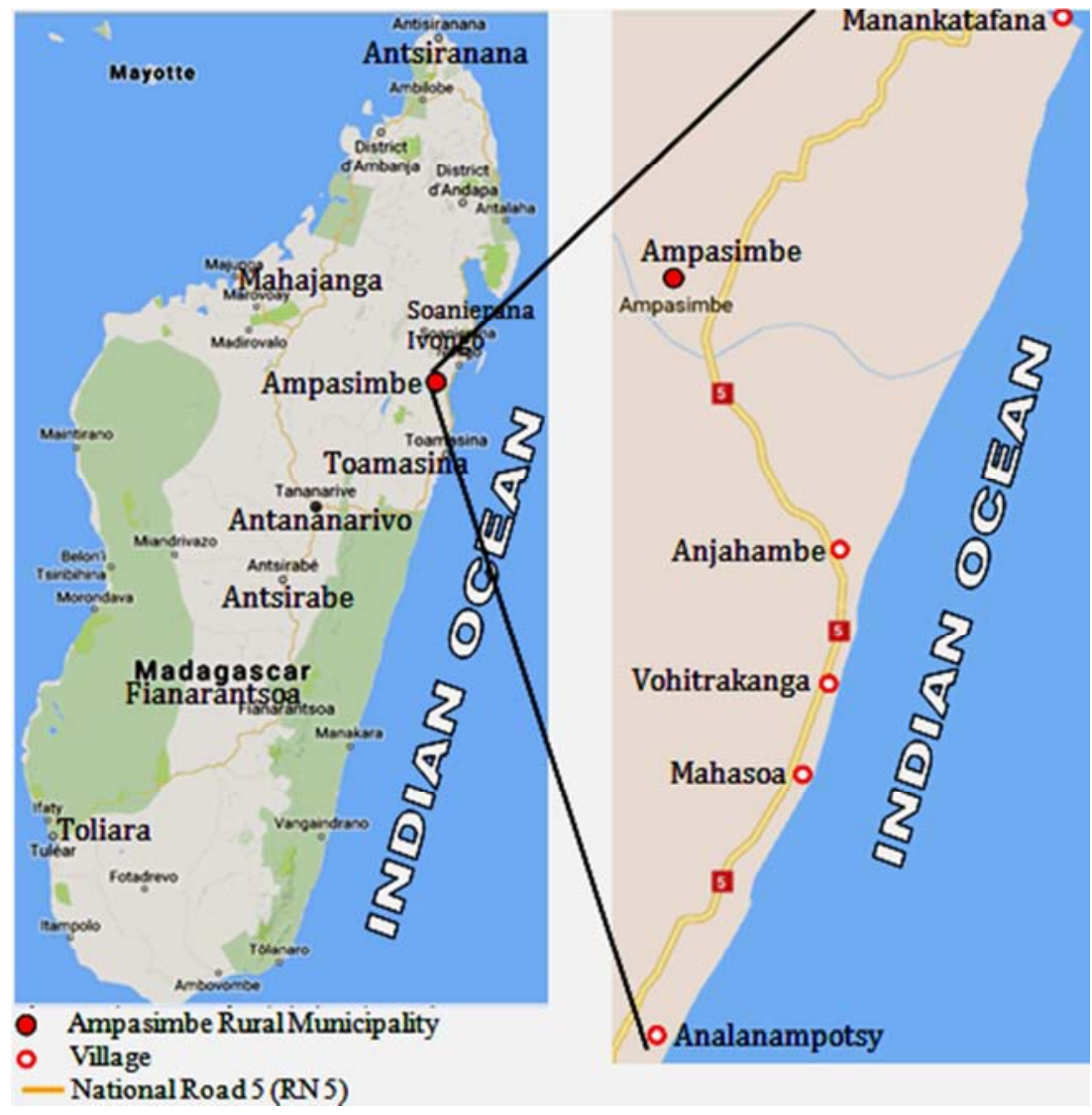

Figure 1. Location of study site.

Several villages have been studied such as Analanampotsy, Mahasoa, Anjahambe, Manankatafana and Vohitrakanga. In addition, the study has been perfomed in all village surrondings in order to rake an approximate area.

\section{Materials and Methods}

\subsection{Dosimetry Methodology}

Measurements have been carried out using GRAETZ X5 DE ratemeter equipped with Geiger Muller detector type whose the measuring range for gamma radiation varies from $0.06 \mu \mathrm{Sv} . \mathrm{h}^{-1}$ to $20 \mathrm{mSv} . \mathrm{h}^{-1}$. The ratemeter detection limit is $0.06 \mu \mathrm{Sv} . \mathrm{h}^{-1}$, values below this limit are not detected. Measurements have been performed at $1 \mathrm{~m}$ above the ground.
In each point of measurement, the geographical coordinates were recorded using a Global Positioning System (GPS) device. In situ, dosimetric measurements were carried out at a variable mesh depending on the expanse of the area of the map. The obtained longitude and latitude were converted in plan coordinates, using Laborde projection.

\subsection{Sampling Strategy}

\subsubsection{Soil Samples}

Soil samples were taken randomly and in the places where measured dose rates were relatively high compared with the mean dose rate value. The samples were put into plastic bags and the quantities varied from $0.5 \mathrm{~kg}$ to $1.0 \mathrm{~kg}$. Each point is recorded by GPS device. The samples are analyzed in terms of radioactivity. 


\subsubsection{Water Samples}

Water samples have been collected in streams, in rivers and underground water. These waters are used by the population as household and drinking water. The samples have been put into plastic bottles of $1.5 \mathrm{~L}$. The geographical coordinates were identified using GPS device.

\subsubsection{Radon in Air}

Measurements of radon were performed in-situ by radon-meter RTM-2100 SARAD. This equipment is able to measure the radioactive gas concentration, especially radon-222. Measurements were carried out inside and outside of sites, in high occupation factor premises or in the populations who live nearby. The affected villages are located within the sites or its surroundings. Measurement times vary from 12 hours to 24 hours depending of the radon concentration level. Similarly, the geographical coordinates of sampling are identified using GPS device. The obtained results were compared with the reference limits, which are 400 Bq. $\mathrm{m}^{-3}$ for the public and 1,000 Bq. $\mathrm{m}^{-3}$ for the workers.

\subsection{Laboratory Works}

All samples were analysed at the "Institut National des
Sciences et Techniques Nucléaires" (INSTN - Madagascar). During sample preparation, soil samples were oven-dried at $80^{\circ} \mathrm{C}$, grinded, sieved, homogenized and placed into $100 \mathrm{~cm}^{3}$ polyethylene cylindrical containers. These containers were hermetically sealed during one month to reach equilibrium of ${ }^{226} \mathrm{Ra}$ and its daugthers before analysis. While water samples were directly put in $500 \mathrm{~cm}^{3}$ Marinelli beakers. Analyzes were performed by gamma spectrometry system, with $\mathrm{NaI}(\mathrm{Tl})$ detector. The samples have been counted between 12 to 24 hours. The equipment is able to measure qualitatively and quantitatively of emitted gamma-rays. The obtained results were compared to the global averages of the same sample types, which are given in reference documents such as UNSCEAR 2000. These values have been used to estimate the minimum and maximum dose rates related to the external exposure, the inhalation and the ingestion.

\subsection{Exposure Dose Assessment}

\subsubsection{Concept}

The basic standard model (UNSCEAR 2000) is used to determine the transfer pathway and to evaluate the dose rates related to the environment natural radioactivity (Figure 2).

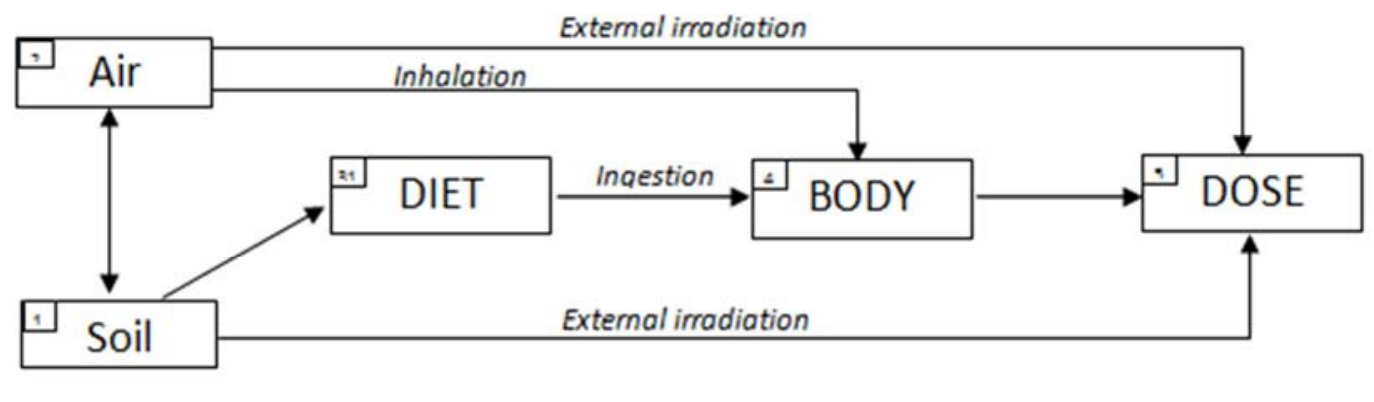

Source: UNSCEAR, 2000

Figure 2. Terrestrial pathways of radionuclide dose transfer.

The main human dose rates are produced by the internal (inhalation and ingestion) and the external exposures. These dose rates proceed mainly from the soil, the air and the food.

\subsubsection{Estimation Method}

The estimation of radiation exposure consists to calculate the doses caused by the concentration of radionuclides in various environmental patterns. The calculation is based on the activity determination. For people living and working in the exposed area, the annual dose rates were determined such as soil and rock radioactivities, internal exposure of drinking water and internal exposure of radon inhalation. Ingestion and inhalation are the most important pathways for the migration of radionuclides inside the human body.

Estimation dose rates are calculated according to the three following hypotheses:

1. For external exposure, the annual working duration is 8 hours per day, 5 days per week and 52 weeks. The outdoor absorbed dose rate $(\dot{D})$, at $1 \mathrm{~m}$ above the ground level, is calculated using equation $1[1,2,3]$.

$$
\dot{\mathrm{D}}\left(\mathrm{nGy} \cdot \mathrm{h}^{-1}\right)=\left(0.462 \times \mathrm{C}_{\mathrm{U}}\right)+\left(0.604 \times \mathrm{C}_{\mathrm{Th}}\right)+\left(0.0417 \times \mathrm{C}_{\mathrm{K}}\right)
$$

where $0.462,0.604$ and 0.0417 are the dose coefficients (nGy. $\mathrm{h}^{-1}$ per Bq. $\mathrm{kg}^{-1}$ ) for ${ }^{238} \mathrm{U},{ }^{232} \mathrm{Th}$ and ${ }^{40} \mathrm{~K}$ respectively. $\mathrm{C}_{\mathrm{U}}, \mathrm{C}_{\mathrm{Th}}$ and $\mathrm{C}_{\mathrm{K}}$ are the activity $\left(\mathrm{Bq} . \mathrm{kg}^{-1}\right)$ of ${ }^{238} \mathrm{U},{ }^{232} \mathrm{Th}$ and ${ }^{40} \mathrm{~K}$ respectively.

The annual effective dose rate per year is calculated by the following relation (2):

$$
\dot{\mathrm{D}}\left(\mathrm{mSv} \cdot \mathrm{y}^{-1}\right)=\dot{\mathrm{D}}\left(\mathrm{nGy} \cdot \mathrm{h}^{-1}\right) \times(8 \times 5 \times 52) \times 0,7 \times 10^{-6}
$$

UNSCEAR 1993 reported, the conversion coefficient for adult is $0.7 \mathrm{~Sv}$. Gy-1 [4].
2. For ingestion, the annual average consumption is about 500 liters. The estimation of dose rate is calculated from 
226Ra activity because of its dissolution in water. The annual effective dose rate is given by the following formula (3):

$$
\dot{\mathrm{D}}\left(\mathrm{mSv} \cdot \mathrm{y}^{-1}\right)=\left(0.28 \times \mathrm{C}_{\mathrm{Ra}}\right) \times 500 \times 10^{-3}
$$

where 0.28 is the conversion factor $\left(\mu \mathrm{Sv} . \mathrm{Bq}^{-1}\right)$ of ${ }^{226} \mathrm{Ra}$ and $\mathrm{C}_{\mathrm{Ra}}$ is the activity (Bq. $\mathrm{L}^{-1}$ ).

3. For inhalation, the annual duration in confined place is 7000 hours. The annual effective dose rate is calculated by the following formula (4):

$$
\dot{\mathrm{D}}\left(\mathrm{mSv} \cdot \mathrm{y}^{-1}\right)=\mathrm{C}_{\mathrm{Rn}} \times 0.4 \times 7000 \times 9 \times 10^{-6}
$$

where $C_{R n}$ is the ${ }^{222} \mathrm{Rn}$ concentration $\left(\mathrm{Bq} . \mathrm{m}^{-3}\right)$. The dose conversion factor is $9 \mathrm{nSv} / \mathrm{Bqh} . \mathrm{m}^{-3}[\mathrm{U} 3, \mathrm{U} 4]$ which it is still considered as appropriate calculation of average effective dose. According to UNSCEAR 2000, the indoor equilibrium factor is 0.4 .

The exposure doses are reported in minimum and maximum values.

The calculated values of the total absorbed dose rate of the all samples (soil, water and air) measured are represented in Table 7.

\section{Results and Discussions}

\subsection{Dosimetric Results}

In total, 272 ambiante dose rate points have been measured of which 250 points spreaded inside of mining area and 22 points in Analanampotsy storage zone of ilmenite and zircon ores (Table 2). In addition, five villages arround the mining zone have been also performed such as Rural Commune of Ampasimbe Manantsatrana (Table 1). The minimum and maximum values have been gathered. The ratemeter detection limit is up to $0.06 \mu \mathrm{Sv} . \mathrm{h}^{-1}$, in which values below this limit cannot be measured. However, these low values do not present hazards either to the public or to workers. The measured exposure dose rates vary from $0.06 \mu \mathrm{Sv} . \mathrm{h}^{-1}$ to $16.20 \mu \mathrm{Sv} . \mathrm{h}^{-1}$. The values show that environmental radioactivity levels in the studied areas vary according to the geological formation of the environment. In comparison with regulatory limits, measured dose rates are below the limit values which are $2.5 \mu \mathrm{Sv} . \mathrm{h}^{-1}$ for public and $7.5 \mu \mathrm{Sv} . \mathrm{h}^{-1}$ for worker $[7,8,9]$.

At Analanampotsy village where the zircon and ilmenite ores have been stored, the dose rates exceeded the limit values. The maximum dose rates of $2.80 \mu \mathrm{Sv} . \mathrm{h}^{-1}$ and $16.20 \mu \mathrm{Sv} . \mathrm{h}^{-1}$ were found in ilmenite and zircon storages respectively. The last value is higher than the controlled area limit value of 7.5 $\mu \mathrm{Sv} . \mathrm{h}^{-1}[7,8,9]$.

Table 1. Exposure dose rates measured in mining sites and in villages at Rural Commune of Ampasimbe Manantsatrana.

\begin{tabular}{llll}
\hline Location & Number of measurements (Village/Site) & Minimum value $\left(\boldsymbol{\mu} \mathbf{S v} . \mathbf{h}^{-1}\right)$ & ${\text { Maximum value }\left(\boldsymbol{\mu S v} . \mathbf{h}^{-1}\right)}$ \\
\hline Analanampotsy & $88(23 / 65)$ & 0.07 & 0.48 \\
Anjahambe & $72(42 / 30)$ & $<0.06$ & 0.32 \\
Mahasoa & $28(28 / 00)$ & 0.07 & 0.24 \\
Vohitrakanga & $21(21 / 00)$ & 0.06 & 0.13 \\
Manankatafana & $41(25 / 16)$ & $<0.06$ & 0.27 \\
Total & $250(139 / 111)$ & - & - \\
\hline
\end{tabular}

\begin{tabular}{|c|c|c|c|c|c|}
\hline \multirow[b]{2}{*}{ Location } & \multirow{2}{*}{$\begin{array}{l}\text { Number of } \\
\text { measurements }\end{array}$} & \multicolumn{2}{|c|}{ Storage area of ilmenite ore } & \multicolumn{2}{|c|}{ Storage area of zircon ore } \\
\hline & & $\begin{array}{l}\begin{array}{l}\text { Minimum value } \\
\left(\mathrm{mSv} \cdot \mathrm{h}^{-1}\right)\end{array} \\
\end{array}$ & $\begin{array}{l}\text { Maximum value } \\
\left(\mathrm{mSv}^{\left.-h^{-1}\right)}\right.\end{array}$ & $\begin{array}{l}\begin{array}{l}\text { Minimum value } \\
\left(\mathrm{mSv}^{-1} \mathbf{h}^{-1}\right.\end{array} \\
\end{array}$ & $\begin{array}{l}\text { Maximum value } \\
\left(\mathrm{mSv}^{-1} \mathbf{h}^{-1}\right.\end{array}$ \\
\hline Anjahambe & - & - & - & - & - \\
\hline Analanampotsy & 22 & 0.20 & 2.80 & 11.80 & 16.20 \\
\hline Mahasoa & - & - & - & - & - \\
\hline Vohitrakanga & - & - & - & - & - \\
\hline Manankatafana & - & - & - & - & - \\
\hline Total & 22 & 0.20 & 2.80 & 11.80 & 16.20 \\
\hline
\end{tabular}

Table 2. Limit values of exposure dose rates measured in temporary storage of mining sites.

Tables 3. Minimun and maximum values of specific radioactivity of soil samples.

1. Site of Analanampotsy

\begin{tabular}{llll}
\hline \multirow{2}{*}{ Number of samples } & \multirow{2}{*}{ Radionuclide } & Activity $\left(\mathbf{B q} \cdot \mathbf{~ k g}^{-\mathbf{1}}\right)(\mathbf{c o n t e n t})$ \\
\cline { 3 - 3 } & & Minimum & Maximum \\
\hline \multirow{2}{*}{ Potassium } & $327 \pm 16$ & $1045 \pm 117$ \\
& & $(1.01 \pm 0.05) \%$ & $(3.23 \pm 0.36) \%$ \\
07 & $910 \pm 64$ & $87160 \pm 28872$ \\
& \multirow{2}{*}{ Thorium } & $(224 \pm 16) \mathrm{ppm}$ & $(21484 \pm 7117) \mathrm{ppm}$ \\
& \multirow{3}{*}{ Uranium } & $437 \pm 99$ & $17295 \pm 6779$ \\
& $(35 \pm 8) \mathrm{ppm}$ & $(1400 \pm 549) \mathrm{ppm}$ \\
\hline
\end{tabular}


2. Site of Anjahambe

\begin{tabular}{|c|c|c|c|}
\hline \multirow{2}{*}{ Number of samples } & \multirow{2}{*}{ Radionuclides } & \multicolumn{2}{|c|}{ Activity (Bq. kg ${ }^{-1}$ ) (content) } \\
\hline & & Minimum & Maximum \\
\hline \multirow{3}{*}{03} & Potassium & $\begin{array}{l}222 \pm 18 \\
(0.7 \pm 0.07) \%\end{array}$ & $\begin{array}{l}616 \pm 31 \\
(1.9 \pm 0.1) \%\end{array}$ \\
\hline & Thorium & $\begin{array}{l}3505 \pm 255 \\
(864 \pm 63) \mathrm{ppm}\end{array}$ & $\begin{array}{l}11004 \pm 930 \\
(2712 \pm 229) \mathrm{ppm}\end{array}$ \\
\hline & Uranium & $\begin{array}{l}1123 \pm 253 \\
(91 \pm 20) \mathrm{ppm}\end{array}$ & $\begin{array}{l}5034 \pm 1166 \\
(408 \pm 94) \mathrm{ppm}\end{array}$ \\
\hline \multicolumn{4}{|c|}{ 3. Site of Manankatafana } \\
\hline \multirow{2}{*}{ Number of samples } & \multirow{2}{*}{ Radionuclides } & \multicolumn{2}{|c|}{ Activity (Bq. $\mathrm{kg}^{-1}$ ) (content) } \\
\hline & & Minimum & Maximum \\
\hline \multirow{3}{*}{02} & Potassium & $\begin{array}{l}161 \pm 7 \\
(0.5 \pm 0.02) \%\end{array}$ & $\begin{array}{l}343 \pm 27 \\
(1.1 \pm 0.08) \%\end{array}$ \\
\hline & Thorium & $\begin{array}{l}1574 \pm 112 \\
(388 \pm 28) \mathrm{ppm}\end{array}$ & $\begin{array}{l}15391 \pm 1328 \\
(3794 \pm 327) \mathrm{ppm}\end{array}$ \\
\hline & Uranium & $\begin{array}{l}444 \pm 99 \\
(36 \pm 8) \mathrm{ppm}\end{array}$ & $\begin{array}{l}3199 \pm 738 \\
(259 \pm 60) \mathrm{ppm}\end{array}$ \\
\hline
\end{tabular}

Table 4. Reference values in the specific radioactivity in soils.

\begin{tabular}{llc}
\hline Radionuclide & Average value (Minimum - Maximum) \\
\hline Potassium & $400(140-850) \mathrm{Bq}_{\mathrm{kg}}^{-1}$ & $1.2(0.4-2.6) \%$ \\
Thorium & $30(11-64) \mathrm{Bq} \cdot \mathrm{kg}^{-1}$ & $7(3-16) \mathrm{ppm}$ \\
Uranium & $35(16-110) \mathrm{Bq}_{\mathrm{kg}} \mathrm{kg}^{-1}$ & $3(1.3-8.9) \mathrm{ppm}$ \\
\multirow{2}{*}{$\mathrm{Th} / \mathrm{U}$ ratio } & Roches primaires & $3.5(3.5-6.3)$ \\
& Soils and sands & $5(1.5-21)$ \\
\hline
\end{tabular}

Source: UNSCEAR 2000 and J. J. W. ROGERS, J. A. S. ADAMS - Handbookof Geochemistry

\subsection{Radioactivity of Water Samples}

Table 5. Specific Radioactivity in water samples.

\begin{tabular}{|c|c|c|c|}
\hline \multirow{2}{*}{ Number of samples } & \multirow{2}{*}{ Radionuclides } & \multicolumn{2}{|c|}{ Activity (Bq. L $\left.^{-1}\right)$} \\
\hline & & Minimum & Maximum \\
\hline \multirow{3}{*}{08} & Potassium & $6.9 \pm 0.2$ & $36.2 \pm 1.4$ \\
\hline & Thorium & $3.4 \pm 0.2$ & $17.7 \pm 1.2$ \\
\hline & Uranium & $0.6 \pm 0.1$ & $19.5 \pm 4.4$ \\
\hline
\end{tabular}

The results show the normal values of specific radioactivity for the water samples. It can be deduced that the radionuclides contained in material radioactive ores in the investigated area not contaminate the surrounding waters. However, special precautions must be taken into consideration.

\subsection{Specific Radioactivity of Radon from Air}

Summary values of the emanation of radon in air are showed in Table 6.

The measurement values are given in average concentrations of which all are below of reference value. Similarly for acceptable values of public of $400 \mathrm{~Bq} . \mathrm{m}^{-3}$ and worker of $1000 \mathrm{~Bq} . \mathrm{m}^{-3}$, the measured values are relatively low. On the one hand, this can be explained that the existence of constantly sea wind blows along the coastline and contributes to scatter of radioactive gases in suspension; on the other hand by the natural ventilation of local dwellings. Modern architecture of buildings in the camp (floors, sealed walls) also contributes to attenuate the emanation phenomenon of radon gas from the soil surface.

Table 6. Specific radioactivity of radon gas in air.

\begin{tabular}{lllll}
\hline \multirow{2}{*}{ Code } & \multirow{2}{*}{ Counting time (hour) } & \multicolumn{2}{l}{ Concentration (Bq. $\mathbf{~ m}^{-3}$ ) } & Maximum \\
\cline { 3 - 5 } & & Average & Minimum & $<1.2$ \\
\hline R01 / Anjahambe & 12 & 81.2 & - & $15 \pm 2$ \\
R02 / Anjahambe & 12 & $8.1 \pm 3.1$ & $7.7 \pm 1.2$ & $16 \pm 2$ \\
R03 / Anjahambe & 24 & $2.6 \pm 1.4$ & $2.3 \pm 1$ & $10 \pm 1$ \\
R04 / Anjahambe & 12 & $7.1 \pm 3.6$ & $3.2 \pm 1.6$ & 480 \\
Reference value & - & 46 & - & \\
\hline
\end{tabular}

\subsection{Minimum and Maximum Exposure Doses}

The estimated Internal and External exposure doses for humans staying and working on sites or its surroundings are calculated from the environmental samples. The summary results are given in Table 7. 
Table 7. Minimum and maximum of calculated exposure dose rates.

\begin{tabular}{llll}
\hline \multirow{2}{*}{ Origin } & Exposure pathway & \multicolumn{2}{l}{ Calculated annual dose rate (mSv. $\left.\mathbf{y}^{-1}\right)$} \\
\cline { 3 - 4 } & & Minimum & Maximum \\
\hline Soil & External & $1.1 \pm 0.0$ & $87.88 \pm 12.93$ \\
Water & Internal (ingestion) & $0.08 \pm 0.0$ & $2.73 \pm 0.62$ \\
Air & Internal (inhalation) & $0.03 \pm 0.0$ & $0.40 \pm 0.05$ \\
Total & & $1.21 \pm 0.0$ & $91.01 \pm 12.91$ \\
Reference value & $1-20$ & & \\
\hline
\end{tabular}

In assumption of a person constantly working near of high radioactive level, the estimated maximum value of annual exposure dose rates is $(91.01 \pm 12.91) \mathrm{mSv} . \mathrm{y}^{-1}$. This rate is calculated from the zircon samples, the temporary storage and the current operation sites. The obtained value is widely higher than the annual limit value of $20 \mathrm{mSv} . \mathrm{y}^{-1}$ for workers $[7,8,9]$.

\section{Conclusion}

The exposure dose rate values vary from $0.06 \mu \mathrm{Sv} . \mathrm{h}^{-1}$ to 16.20 $\mu \mathrm{Sv} . \mathrm{h}^{-1}$. The measured exposure doses inside and around the villages are below the acceptable limit value for the public. In the mining sites and outside of storage areas, values do not exceed the controlled area limit value for workers. In storage areas, some values exceed the controlled area limit value. The maximum value was obtained in the temporary storage area of zircon mining site of Analanampotsy.

For soil sample measurements, the specific activities values are higher than the world reference given by the Table 4 .

For water sample, the specific activities values are relatively in the order of world reference magnitude.

In-situ, radon gas measurements show that the average concentrations in the air are below the reference value provided by the Table 6 . Taking the assumption that a person is staying constantly in the vicinity of high radioactivity area, the maximum exposure rate is $(91.01 \pm 12.91) \mathrm{mSv}^{-\mathrm{y}^{-1}}$. Such value is higher than the regulatory limit for workers $(20 \mathrm{mSv}$. $\left.\mathrm{y}^{-1}\right)[7,8,9]$.

In comparison of available data, the obtained dose rate levels in the all investigated sites are lower than the beach sand from Guarapari (Brazil) $90 \mu \mathrm{Sv} . \mathrm{h}^{-1}$ (UNSCEAR 2000).

\section{Appendix}

Table A1. Radioactivity of soil samples.

\begin{tabular}{|c|c|c|c|c|c|c|}
\hline \multirow{2}{*}{ Code } & \multicolumn{3}{|c|}{ Activity (Bq. kg-1) } & \multicolumn{3}{|l|}{ Content (ppm) } \\
\hline & ${ }^{40} \mathrm{~K}$ & ${ }^{232} \mathrm{Th}$ series & ${ }^{238} \mathrm{U}$ series & ${ }^{40} \mathrm{~K}$ & ${ }^{232} \mathrm{Th}$ & ${ }^{238} \mathbf{U}$ \\
\hline S01 & $1045 \pm 117$ & $7535 \pm 823$ & $3206 \pm 783$ & $32306 \pm 3630$ & $1857 \pm 203$ & $260 \pm 63$ \\
\hline $\mathrm{S} 02$ & $<854$ & $57825 \pm 13239$ & $14780 \pm 4822$ & $<26392$ & $14253 \pm 3263$ & $1197 \pm 390$ \\
\hline S03 & $663 \pm 33$ & $2140 \pm 158$ & $437 \pm 99$ & $20505 \pm 1023$ & $528 \pm 39$ & $35 \pm 8$ \\
\hline S04 & $327 \pm 16$ & $1861 \pm 137$ & $681 \pm 153$ & $10109 \pm 506$ & $459 \pm 34$ & $55 \pm 12$ \\
\hline S05 & $619 \pm 27$ & $910 \pm 64$ & $461 \pm 103$ & $19142 \pm 821$ & $224 \pm 16$ & $37 \pm 8$ \\
\hline S06 & $<878$ & $63398 \pm 17735$ & $17295 \pm 6779$ & $<27133$ & $15627 \pm 4371$ & $1400 \pm 549$ \\
\hline S07 & $<900$ & $87160 \pm 28872$ & $16606 \pm 7255$ & $<27831$ & $21484 \pm 7117$ & $1345 \pm 587$ \\
\hline S08 & $<273$ & $3505 \pm 255$ & $1419 \pm 319$ & $<8455$ & $864 \pm 63$ & $115 \pm 26$ \\
\hline S09 & $616 \pm 31$ & $3732 \pm 274$ & $1123 \pm 253$ & $19051 \pm 951$ & $920 \pm 67$ & $91 \pm 20$ \\
\hline S10 & $222 \pm 18$ & $11004 \pm 930$ & $5034 \pm 1166$ & $6866 \pm 561$ & $2712 \pm 229$ & $408 \pm 94$ \\
\hline S11 & $161 \pm 7$ & $1574 \pm 112$ & $444 \pm 99$ & $4965 \pm 231$ & $388 \pm 28$ & $36 \pm 8$ \\
\hline $\mathrm{S} 12$ & $343 \pm 27$ & $15391 \pm 1328$ & $3199 \pm 738$ & $10611 \pm 843$ & $3794 \pm 327$ & $259 \pm 60$ \\
\hline
\end{tabular}

Table A2. Geographical coordinates of soil samples.

\begin{tabular}{|c|c|c|c|}
\hline Code & Location & Latitude (S) & Longitude (E) \\
\hline S01 & \multirow{6}{*}{ Analanampotsy } & $17^{\circ} 09^{\prime} 42,5^{\prime \prime}$ & $49^{\circ} 29^{\prime} 12,7^{\prime \prime}$ \\
\hline S02 & & $17^{\circ} 09^{\prime} 43,1^{\prime \prime}$ & $49^{\circ} 29^{\prime} 12,5^{\prime \prime}$ \\
\hline S03 & & $17^{\circ} 09^{\prime} 44,5^{\prime \prime}$ & $49^{\circ} 29^{\prime} 10,3^{\prime \prime}$ \\
\hline S04 & & $17^{\circ} 09^{\prime} 51,9^{\prime \prime}$ & $49^{\circ} 29^{\prime} 05,7^{\prime \prime}$ \\
\hline S05 & & $17^{\circ} 09^{\prime} 48,1^{\prime \prime}$ & $49^{\circ} 29^{\prime} 09,8^{\prime \prime}$ \\
\hline S06 & & $17^{\circ} 10^{\prime} 11,8^{\prime \prime}$ & $49^{\circ} 28^{\prime} 56,4^{\prime \prime}$ \\
\hline S08 & \multirow{3}{*}{ Anjahambe } & $17^{\circ} 07^{\prime} 12,8^{\prime \prime}$ & $49^{\circ} 30^{\prime} 16,4^{\prime \prime}$ \\
\hline S09 & & $17^{\circ} 06^{\prime} 42,8^{\prime \prime}$ & $49^{\circ} 30^{\prime} 29,3^{\prime \prime}$ \\
\hline $\mathrm{S} 10$ & & $17^{\circ} 07^{\prime} 43,8^{\prime \prime}$ & $49^{\circ} 30^{\prime} 08,4^{\prime \prime}$ \\
\hline S11 & \multirow{2}{*}{ Manankatafana } & $17^{\circ} 04^{\prime} 24,8^{\prime \prime}$ & $49^{\circ} 31^{\prime} 25,3^{\prime \prime}$ \\
\hline $\mathrm{S} 12$ & & $17^{\circ} 04^{\prime} 21,6^{\prime \prime}$ & $49^{\circ} 31^{\prime} 26,2^{\prime \prime}$ \\
\hline
\end{tabular}


Table A3. Radioactivity of water samples.

\begin{tabular}{llll}
\hline \multirow{2}{*}{ Code } & Activité (Bq. L-1) & & \\
\cline { 2 - 4 } & ${ }^{40} \mathbf{K}$ series & ${ }^{232}$ Th series & $11,8 \pm 2,6$ \\
\hline W01 & $32,0 \pm 1,2$ & $10,6 \pm 0,7$ & $19,5 \pm 4,4$ \\
W02 & $17,1 \pm 0,6$ & $<12$ & $10,1 \pm 2,3$ \\
W03 & $<112$ & $17,7 \pm 1,2$ & $3,6 \pm 0,8$ \\
W04 & $7,3 \pm 0,3$ & $16,5 \pm 1,1$ & $8,7 \pm 1,9$ \\
W05 & $13,4 \pm 0,5$ & $3,4 \pm 0,2$ & $8,7 \pm 1,2$ \\
W06 & $6,9 \pm 0,2$ & $16,9 \pm 1,2$ & $10,5 \pm 2,3$ \\
W07 & $36,2 \pm 1,4$ & $8,1 \pm 0,6$ & $0,6 \pm 0,1$ \\
W08 & $12,3 \pm 0,4$ & $17,7 \pm 1,2$ & ${ }^{238}$ series \\
\hline
\end{tabular}

Table A4. Geographical coordinates of water samples.

\begin{tabular}{llll}
\hline Code & Location & Latitude (S) & Longitude (E) \\
\hline W01 & Analanampotsy & $17^{\circ} 07^{\prime} 24,5^{\prime \prime}$ & $49^{\circ} 30^{\prime} 08,8^{\prime \prime}$ \\
W02 & & $17^{\circ} 09^{\prime} 42,9^{\prime \prime}$ & $49^{\circ} 29^{\prime} 12,4^{\prime \prime}$ \\
W03 & & $1^{\circ} 09^{\prime} 43,0^{\prime \prime}$ & $49^{\circ} 29^{\prime} 12,0^{\prime \prime}$ \\
W04 & & $1^{\circ} 09^{\prime} 42,4^{\prime \prime}$ & $49^{\circ} 29^{\prime} 12,1^{\prime \prime}$ \\
W05 & & $7^{\circ} 06^{\prime} 24,9^{\prime \prime}$ & $49^{\circ} 30^{\prime} 36,5^{\prime \prime}$ \\
W06 & Anjahambe & $1^{\circ} 03^{\prime} 34,4^{\prime \prime}$ & $49^{\circ} 31^{\prime} 26,8^{\prime \prime}$ \\
W07 & Manakatafana & $17^{\circ} 06^{\prime} 00,6^{\prime \prime}$ & $49^{\circ} 30^{\prime} 32,7^{\prime \prime}$ \\
W08 & & $17^{\circ} 05^{\prime} 51,1^{\prime \prime}$ & $49^{\circ} 29^{\prime} 55,3^{\prime \prime}$ \\
\hline
\end{tabular}

Table A5. Specific radioactivity of radon gas in air.

\begin{tabular}{lllll}
\hline \multirow{2}{*}{ Code } & \multirow{2}{*}{ Time of measurement (hours) } & \multicolumn{2}{l}{ Concentration of radon $\left(\right.$ Bq. $\left.\mathbf{~ m}^{-3}\right)$} \\
\cline { 3 - 5 } & & Average & Minimum & Maximum \\
\hline R01/Anjahambe & $12 \mathrm{~h}$ & $<1,2$ & - & $<1,2$ \\
R02/Anjahambe & $12 \mathrm{~h}$ & $8,1 \pm 3,1$ & $7,7 \pm 1,2$ & $15 \pm 2$ \\
R03/Anjahambe & $24 \mathrm{~h}$ & $2,6 \pm 1,4$ & $2,3 \pm 1$ & $16 \pm 2$ \\
R04/Anjahambe & $12 \mathrm{~h}$ & $7,1 \pm 3,6$ & $3,2 \pm 1,6$ & $10 \pm 1$ \\
\hline
\end{tabular}

Table A6. Geographical coordinates (radon in air).

\begin{tabular}{llll}
\hline Code & Location & Latitude & Longitude \\
\hline R01 & & $17^{\circ} 07^{\prime} 25,0^{\prime \prime}$ & $49^{\circ} 30^{\prime} 09,3^{\prime \prime}$ \\
R02 & Anjahambe & $17^{\circ} 07^{\prime} 25,1^{\prime \prime}$ & $49^{\circ} 30^{\prime} 09,4^{\prime \prime}$ \\
R03 & & $17^{\circ} 07^{\prime} 24,4^{\prime \prime}$ & $49^{\circ} 30^{\prime} 05,8^{\prime \prime}$ \\
R04 & & $17^{\circ} 07^{\prime} 24,4^{\prime \prime}$ & $49^{\circ} 30^{\prime} 05,8^{\prime \prime}$ \\
\hline
\end{tabular}

\section{References}

[1] United Nations Scientific Committee on the Effects of Atomic Radiation, UNSCEAR 2000 Report to the General Assembly, with Scientific Annexes, UNITED NATIONS, New York, 2000 .

[2] United Nations Scientific Committee on the Effects of Atomic Radiation (UNSCEAR). Report to the General Assembly, vol. 1, Annex. B; 2008.

[3] United Nations Scientific Committee on the Effects of Atomic Radiation (UNSCEAR). Sources and effects of ionizing radiation. Report to the General Assembly, Annexe B; 2000.

[4] United Nations Scientific Committee on the Effects of Atomic Radiation, UNSCEAR 1993 Report to the General Assembly, with Scientific Annexes, UNITED NATIONS, New York, 1993.

[5] R. Veiga et al. / Radiation Measurements 41 (2006) 189-196, Measurement of natural radioactivity in Brazilian beach sands.

[6] N. Karunakara et al. / Results in Physics 4 (2014) 20-27, Assessment of ambient gamma dose rate around a prospective uranium mining area of South India - A comparative study of dose by direct methods and soil radioactivity measurements.

[7] ICPR PUBLICATION 103, the 2007 Recommendations of the International Commission on Radiological Protection, French Edition by Jean Claude Nénot assisted by Jean Brenot, Dominique Laurier, Alain Rannou and Dominique Thierry.

[8] Édition en langue française par Jean-Claude Nénot assisté de Jean Brenot, Dominique Laurier, Alain Rannou et Dominique Thierry.

[9] INTERNATIONAL ATOMIC ENERGY AGENCY, Radiation Protection and Safety of Radiation Sources, International Basic Safety Standards, Interim Edition, GSR Part 3, VIENNA, 2011.

[10] INTERNATIONAL ATOMIC ENERGY AGENCY, International Basic Safety Standards for Protection Against Ionizing Radiation and for the Safety of Radiation Sources, Safety Series No 115, VIENNA, 1996.

[11] J. J. W. Rogers and J. A. S. Adams, "Thorium," In: K. H. Wedepohl, Ed., Handbook of Geochemistry, Berlin, 1969.

[12] LEGISLATION ON RADIATION PROTECTION IN MADAGASCAR, LAW 97-041 on 02 January 1998. 